\title{
Synthesis, Crystal Structure and Properties of the Cyano-bridged Heteropolynuclear $[\mathrm{Cu}(\text { meso })]_{3}\left[\mathrm{Co}(\mathrm{CN})_{6}\right]_{2} \cdot 9.5 \mathrm{H}_{2} \mathrm{O}$ Compound
}

\author{
Fabiana H. O. Ishiruji, ${ }^{a}$ Nivaldo L. Speziali, ${ }^{b}$ Maria G. F. Vaz ${ }^{c}$ and Fábio S. Nunes ${ }^{*, a}$ \\ ${ }^{a}$ Departamento de Química, Universidade Federal do Paraná, CP 19081, \\ 81531-990 Curitiba-PR, Brazil
}

${ }^{b}$ Departamento de Física, Universidade Federal de Minas Gerais-ICEx, CP 702, 30123-970 Belo Horizonte-MG, Brazil

${ }^{c}$ Instituto de Química, Universidade Federal Fluminense, Outeiro de São João Batista s/n, Campus do Valonguinho, Centro, Niterói-RJ, Brazil

O composto $[\mathrm{Cu}(\text { meso })]_{3}\left[\mathrm{Co}(\mathrm{CN})_{6}\right]_{2} \cdot 9.5 \mathrm{H}_{2} \mathrm{O}$ foi preparado e caracterizado por difratometria de raios X de monocristal, e por suas propriedades espectrais (UV-vis, FTIR, EPR) e magnéticas. A estrutura cristalina mostrou a formação de um polímero com conformação zigzag produzido pela combinação espontânea das unidades $[\mathrm{Cu}(\text { meso })]^{2+} \mathrm{e}\left[\mathrm{Co}(\mathrm{CN})_{6}\right]^{3-}$, na proporção estequiométrica de 3:2. Unidades isoladas de $\left[\mathrm{Cu}(\text { meso })\left(\mathrm{H}_{2} \mathrm{O}\right)_{2}\right]^{2+}$ completam o balanço de carga do polímero. $\mathrm{O}$ empacotamento cristalino exibe cavidades contendo um grande número de moléculas de água. As propriedades magnéticas do polímero mostraram um acoplamento antiferromagnético fraco entre os íons de cobre, com constante de acoplamento $J=-0,3 \mathrm{~cm}^{-1}$. Espectros de absorção na região do infravermelho apresentaram bandas típicas dos modos vibracionais $\mathrm{v}(\mathrm{O}-\mathrm{H}) \mathrm{em} 3604 \mathrm{~cm}^{-1} \mathrm{e}$ $v(\mathrm{CN}) \mathrm{em} 2184 \mathrm{e} 2128 \mathrm{~cm}^{-1}$ referentes aos ligantes cianeto em ponte e equatoriais, respectivamente. O espectro eletrônico do composto exibiu uma banda larga e simétrica em $547 \mathrm{~nm}$, atribuída à sobreposição das seguintes transições $z^{2} \rightarrow x^{2}-y^{2}$, xy $\rightarrow x^{2}-y^{2}$ and (xz, yz) $\rightarrow x^{2}-y^{2}$. O espectro de EPR a $77 \mathrm{~K}$ apresentou um padrão típico de 4 linhas com valores de $\mathrm{g}_{/ /}=2,33$ e $\mathrm{g}_{\perp}=2,01$ característicos de um sistema $\mathrm{S}=1 / 2$ com simetria axial, coerente com a distorção tetragonal observada para o íon cobre(II) pelas distâncias cristalográficas.

The novel compound $[\mathrm{Cu}(\text { meso })]_{3}\left[\mathrm{Co}(\mathrm{CN})_{6}\right]_{2} \cdot 9.5 \mathrm{H}_{2} \mathrm{O}$ was prepared and characterized structurally, magnetically and spectroscopically (UV-vis, FTIR and EPR). The crystal structure is result of the self-assembly of three $[\mathrm{Cu}(\text { meso })]^{2+}$ and two $\left[\mathrm{Co}(\mathrm{CN})_{6}\right]^{3-}$ units leading to a polymeric zigzag chain. Isolated $\left[\mathrm{Cu}(\text { meso })\left(\mathrm{H}_{2} \mathrm{O}\right)_{2}\right]^{2+}$ units counterbalance the charge of the whole structure. The crystal packing shows a large hollow space in the structure and a significant number of water molecules are found in these cavities. Magnetic properties exhibited a very weak antiferromagnetic exchange interaction between the copper ions, with $J=-0.3 \mathrm{~cm}^{-1}$. FTIR spectrum showed typical frequencies of $\mathrm{v}(\mathrm{O}-\mathrm{H})$ at $3604 \mathrm{~cm}^{-1}$ and bridging and non-bridging $\mathrm{v}(\mathrm{CN})$ at 2184 and $2128 \mathrm{~cm}^{-1}$, respectively. The electronic spectrum of the title complex presented a broad and symmetric band at $547 \mathrm{~nm}$, assigned to the overlaid $\mathrm{z}^{2} \rightarrow \mathrm{x}^{2}-\mathrm{y}^{2}, \mathrm{xy} \rightarrow \mathrm{x}^{2}-\mathrm{y}^{2}$ and (xz, yz) $\rightarrow \mathrm{x}^{2}-\mathrm{y}^{2}$ transitions. EPR data at $77 \mathrm{~K}$ presented a typical axial spectrum with $\mathrm{g}_{/ /}=2.33$ and $\mathrm{g}_{\perp}=2.01$, in accordance with the tetragonal distortion of the copper(II) ion as supported by the single-crystal X ray diffraction data.

Keywords: polynuclear, cyano-bridge, single crystal X-ray diffractometry, antiferromagnetism

\section{Introduction}

There has been a growing progress in the design of supramolecular architectures based on cyanometallate complexes for their relationship to molecular magnetism

*e-mail: fsnunes@quimica.ufpr.br and electronic properties. ${ }^{1-15}$ These building blocks, combined with coordinatively unsaturared systems such as cationic Schiff-bases, produce 1D, 2D or 3D network structures. These assemblies, also called Prussian blue analogues, gained importance due to the innumerous possibilities to prepare novel bimetallic extended lattices. 
Most of these structures contain two different transition metal ions. Cyanide bridges are linear and suitable to communicate spin density as some compounds behave as high-temperature molecular magnets. ${ }^{5}$ The study of electronic and magnetic properties is necessary to a better understanding of potential metal-metal exchange interactions. These properties are intimately related to the structure and are a result of the nature of the building blocks, their relative orientation in the crystal lattice and interactions such as H-bonding and van der Waals. Therefore, controlling preparative methods is a key step in obtaining complexes with the desired structural and physical properties. ${ }^{16,17}$

Our continuing interest in the tetradentate macrocyclic ligand meso $=5,5,7,12,12,14$-hexamethyl-1,4,8,11tetraazacyclotetradecane (Scheme 1) encouraged us to investigate the reaction of $\left[\mathrm{Co}(\mathrm{CN})_{6}\right]^{3-}$ with $[\mathrm{Cu}(\text { meso })]^{2+} .2,18,19$ Herein we report the synthesis and characterization of the new trans-cyano-bridged $[\mathrm{Cu}(\text { meso })]_{3}\left[\mathrm{Co}(\mathrm{CN})_{6}\right]_{2} \cdot 9.5 \mathrm{H}_{2} \mathrm{O}$ coordination polymer.

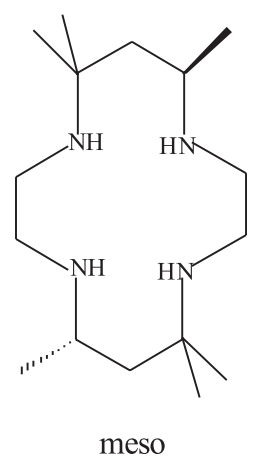

Scheme 1.

\section{Experimental}

\section{Physical measurements and instrumentation}

$\mathrm{X}$-ray diffraction data collection was performed on an Oxford-Diffraction GEMINI-Ultra diffractometer (LabCri) using graphite-Enhance Source $\mathrm{MoK}_{\alpha}$ radiation $(\lambda=0.71069 \AA)$ at $\mathrm{T}=120(2) \mathrm{K}$. Data integration and scaling of the reflections were performed with the Crysalis suite. ${ }^{20}$ Final unit cell parameters were based on the fitting of all reflection positions. Empirical multi-scan absorption corrections using equivalent reflections were performed with the program SCALE3 ABSPACK.$^{21}$

The structure was solved by direct methods using the SHELXS program. ${ }^{22}$ The positions of all atoms could be unambiguously assigned on consecutive difference Fourier maps. Refinements were performed using SHELXL based on $\mathrm{F}^{2}$ through full-matrix least square routine. ${ }^{23}$ Most of the hydrogen atoms, including those bound to nitrogen atoms and those in water molecules, could be identified in the final Fourier difference maps. In the final model refinement those bound to carbon were geometrically positioned and refined using a riding model ${ }^{24}$ for the others, distance restraints were imposed.

The magnetization measurement was performed on a Cryogenic SX-600 SQUID magnetometer in the temperature range 2-298 K with an applied field of 1000 Oe. Diamagnetic correction was evaluated from Pascal's constants.

UV-Vis spectra in the range $190-820 \mathrm{~nm}$ were obtained on a SHIMADZU UVPC 2401 spectrophotometer in dmf solutions.

X-band electron paramagnetic resonance (EPR) spectra were recorded on a Bruker ESP300-E instrument from dmf frozen solutions at $77 \mathrm{~K}$.

Infrared spectra were obtained with a FTS3500GX Bio-Rad Excalibur series spectrophotometer in the region $4000-400 \mathrm{~cm}^{-1}$ in $\mathrm{KBr}$ pellets.

\section{Materials}

Reagent grade chemicals were used in this work. The macrocyclic meso was prepared as published elsewhere. ${ }^{19}$

\section{Preparation of $[\mathrm{Cu}(\text { meso })]_{3}\left[\mathrm{Co}(\mathrm{CN})_{6}\right]_{2} \cdot 9.5 \mathrm{H}_{2} \mathrm{O}$}

$[\mathrm{Cu}$ (meso) $]\left(\mathrm{ClO}_{4}\right)_{2}{ }_{25}^{25}(1.23 \mathrm{~g} ; 2.25 \mathrm{mmol})$ was dissolved under reflux in $50 \mathrm{~mL}$ of water. After, $0.50 \mathrm{~g}(1.52 \mathrm{mmol})$ of $\mathrm{K}_{3}\left[\mathrm{Co}(\mathrm{CN})_{6}\right]$ dissolved in $10 \mathrm{~mL}$ of water was added dropwise. Upon standing overnight at room temperature, purple crystals were colleted by filtration, washed with cold water and dried under vacuum. Yield was $0.65 \mathrm{~g}(42 \%)$. IR absorptions $v_{\max } / \mathrm{cm}^{-1}: 3604 \mathrm{~m} \mathrm{v}(\mathrm{OH}), 3224 \mathrm{~s} v(\mathrm{NH})$, $2976 \mathrm{~m} \mathrm{v}\left(\mathrm{CH}_{2} \mathrm{CH}_{2}\right), 2876 \mathrm{~m} v(\mathrm{CH}), 2128 \mathrm{vs} v(\mathrm{CN})$-bridge, 2184vw v(CN)-terminal, 1462w $\delta(\mathrm{NH}), 1371 \mathrm{w} \delta(\mathrm{CNC})$, $1289 \mathrm{vw} \delta(\mathrm{CNC}), 1189 \mathrm{~m} \gamma(\mathrm{HCH}), 824 \mathrm{vw} \gamma(\mathrm{HCC}), 622 \mathrm{~m}$, $\mathrm{v}(\mathrm{CoC}), 484 \mathrm{w} v(\mathrm{CuN})$ and 1090-1100vs v(ClO). Caution! Perchlorate salts are potentially explosive in the presence of organic substances: any sample heating must be avoided.

\section{Results and Discussion}

\section{Crystallographic structure}

The crystal structure of $[\mathrm{Cu}(\text { meso })]_{3}\left[\mathrm{Co}(\mathrm{CN})_{6}\right]_{2} \cdot 9.5 \mathrm{H}_{2} \mathrm{O}$ is the result of the self-assembly of three $[\mathrm{Cu}(\text { meso })]^{2+}$ and two $\left[\mathrm{Co}(\mathrm{CN})_{6}\right]^{3-}$ units. Figure 1 shows the molecular assembly, where each $\left[\mathrm{Co}(\mathrm{CN})_{6}\right]^{3-}$ linked up to the two nearest $[\mathrm{Cu}(\text { meso })]^{2+}$ via cyano bridges with the following atomic bond distances: Co-C2 1.891(4) $\AA$, C2-

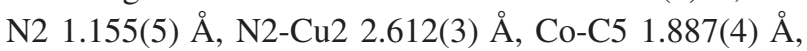


C5-N5 1.158(8) , N5-Cu3 2.737(3) $\AA$. The average non-bridging $\mathrm{CN}$ distance is $1.152(3) \AA$. The $\mathrm{Co}$ III ion lies in a fairly octahedral environment. Mean values for bond lengths of $\mathrm{Co}-\mathrm{C}_{\text {axial }}$ and $\mathrm{Co}-\mathrm{C}_{\text {equatorial }}$ are 1.886 and 1.903 $\AA$, respectively, while C2-Co-C5, N5-C5-Co, C5-Co-C1 angles are $178.20(14)^{\circ}, 176.6(3)$ and $87.23(14)^{\circ}$ in this order. The $\mathrm{Cu}^{\mathrm{II}}$ ion suffers a strong tetragonal distortion as is evidenced by the much longer $\mathrm{Cu}-\mathrm{N}_{\text {axial }}$ bond distances $(\mathrm{Cu} 2-\mathrm{N} 22$ 2.612(3) $\AA$ and $\mathrm{Cu} 3-\mathrm{N} 5$ 2.737(3) $\AA$ ) when compared to the $\mathrm{Cu}-\mathrm{N}_{\text {equatoral }}$ values, in average 2.040(3) $\AA$. The $\mathrm{Cu} 2$ and $\mathrm{Cu} 3$ ions lie very far apart, with a $\mathrm{Cu} \cdots \mathrm{Cu}$ distance of $9.609 \AA$, whereas for adjacent $\mathrm{Co} \cdots \mathrm{Cu}$ distance is 5.245(5) $\AA$. The asymmetric unit for each string is given by $\left[(\text { meso }) \mathrm{Cu}-\mathrm{NC}-\mathrm{Co}(\mathrm{CN})_{5}\right]^{-}$and the charge between two of them is balanced by one isolated $\left[\mathrm{Cu}(\text { meso })\left(\mathrm{H}_{2} \mathrm{O}\right)_{2}\right]^{2+}$ unit. Bond distances and angles in this work are close to the values reported by Mondal and co-workers for $\left[\mathrm{Cu}(\mathrm{dmpn})_{2}\right]_{3}\left[\mathrm{Co}(\mathrm{CN})_{6}\right]_{2} \cdot 12 \mathrm{H}_{2} \mathrm{O}$, which also shows a zigzag conformation of alternate $\left.[\mathrm{Co}(\mathrm{CN})]_{6}\right]^{3-}$ and $\left[\mathrm{Cu}(\mathrm{dmpn})_{2}\right]^{2+}$ ions $(\mathrm{dmpn}=1$-dimethylamino-2-propylamine $) .{ }^{14}$

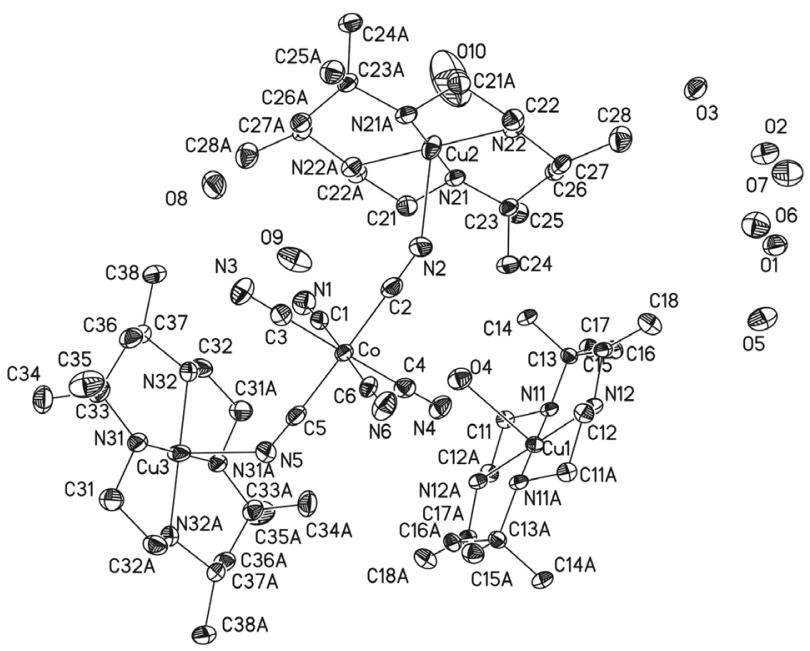

Figure 1. ORTEP view of $[\mathrm{Cu}(\mathrm{meso})]_{3}\left[\mathrm{Co}(\mathrm{CN})_{6}\right]_{2} \cdot 9.5 \mathrm{H}_{2} \mathrm{O}$ with the atom labeling scheme. Hydrogen atoms were omitted for clarity. Thermal ellipsoids are drawn at the $50 \%$ probability level.

The cell unit reveals (Figure 2) the formation of polymeric zigzag chains with a very bent $\mathrm{C} 5-\mathrm{N} 5-\mathrm{Cu} 3$ angle of $132.08(3)^{\circ}$. In the $[\mathrm{Cu}(\text { meso })]^{2+}$ units, each $\mathrm{Cu}$ atom is in an inversion center in the $P-1$ space group and, consequently, only half of the $\mathrm{N}$ and $\mathrm{C}$ atoms are non equivalent; the $\mathrm{Cu}$ and the four $\mathrm{N}$ atoms are on perfect planes. The crystal packing also shows a large hollow space in the structure, which accommodates a significant number of water molecules. There is an extended H-bonding network between the hydrogen and nitrogen atoms of terminal cyanide ligands. Crystallographic parameters and details of data collection and refinement
Table 1. Crystal and structure refinement data for $[\mathrm{Cu}(\mathrm{meso})]_{3}\left[\mathrm{Co}(\mathrm{CN})_{6}\right] \cdot \cdot 9.5 \mathrm{H}_{2} \mathrm{O}$

\begin{tabular}{|c|c|}
\hline Empirical formula & $\mathrm{C}_{30} \mathrm{H}_{74} \mathrm{CoCu}_{1.50} \mathrm{~N}_{12} \mathrm{O}_{10.5}$ \\
\hline Formula weight & 917.25 \\
\hline $\mathrm{T} / \mathrm{K}$ & $120(1)$ \\
\hline Radiation, $\lambda / \AA$ & 1.54180 \\
\hline Crystal system, space group & Triclinic, $P-1$ \\
\hline Unit cell dimensions & $\begin{array}{l}a=9.0274(4) \AA, \alpha=109.276(4)^{\circ} \\
b=14.8014(7) \AA, \beta=102.161(4)^{\circ} \\
c=18.0830(9) \AA, \gamma=92.960(3)^{\circ}\end{array}$ \\
\hline Volume / $\AA^{3}$ & $2210.25(18)$ \\
\hline $\mathrm{Z}$ & 2 \\
\hline Calculated density $/ \mathrm{g} \mathrm{cm}^{-3}$ & 1.378 \\
\hline Absorption coefficient $/ \mathrm{mm}^{-1}$ & 4.295 \\
\hline $\mathrm{F}(000)$ & 977 \\
\hline Crystal size / mm & $0.3 \times 0.25 \times 0.2$ \\
\hline Theta range $/{ }^{\circ}$ & 3.19 to 62.31 \\
\hline Index ranges & $\begin{array}{l}-10 \leq h \leq 10,-16 \leq k \leq 16, \\
-18 \leq l \leq 20\end{array}$ \\
\hline Reflections collected & 11420 \\
\hline Independent reflections & $6703[\mathrm{R}($ int $)=0.0272]$ \\
\hline Completeness to theta $=62.31^{\circ}$ & $95.5 \%$ \\
\hline Max. and min. transmission & 1.00000 and 0.61619 \\
\hline Refinement method & Full-matrix least-squares on $\mathrm{F}^{2}$ \\
\hline Data / restraints / parameters & $6703 / 0 / 496$ \\
\hline Goodness-of-fit on $\mathrm{F}^{2}$ & 1.057 \\
\hline Final $R$ indices $[\mathrm{I}>2 \operatorname{sigma}(\mathrm{I})]$ & $\mathrm{R}_{1}=0.0426, \mathrm{wR}_{2}=0.1119$ \\
\hline $\mathrm{R}$ indices (all data) & $\mathrm{R}_{1}=0.0533, \mathrm{wR}_{2}=0.1179$ \\
\hline Largest diff. peak and hole & 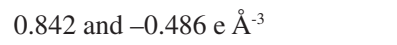 \\
\hline
\end{tabular}

Table 2. Selected bond lengths $(\AA)$ and angles $\left({ }^{\circ}\right)$ for $[\mathrm{Cu}(\text { meso })]_{3}\left[\mathrm{Co}(\mathrm{CN})_{6}\right]_{2} \cdot 9.5 \mathrm{H}_{2} \mathrm{O}$

\begin{tabular}{lccc}
\hline Co-C1 & $1.903(3)$ & C2-Co-C1 & $90.91(16)$ \\
Co-C2 & $1.891(4)$ & C2-Co-C5 & $178.07(17)$ \\
Co-C3 & $1.897(3)$ & C1-Co-C5 & $87.16(16)$ \\
Co-C4 & $1.903(3)$ & C1-Co-C6 & $178.56(16)$ \\
Co-C5 & $1.887(4)$ & C5-N5-Cu3 & $132.9(3)$ \\
Co-C6 & $1.907(3)$ & C22-N22-Cu2 & $105.4(2)$ \\
Cu1-N11 & $2.058(2)$ & N2-Cu2-N21 & $98.38(10)$ \\
Cu1-N12 & $2.022(2)$ & N21-Cu2-N22 & $94.15(10)$ \\
Cu2-N21 & $2.031(3)$ & C21-N21-Cu2 & $106.77(18)$ \\
Cu2-N22 & $2.043(3)$ & O4-Cu1-N11 & $97.85(09)$ \\
Cu3-N31 & $2.040(3)$ & N11-Cu1-N12 & $94.89(10)$ \\
Cu3-N32 & $2.022(3)$ & C11-N11-Cu1 & $106.37(18)$ \\
Cu1-O4 & $2.642(2)$ & & \\
\hline
\end{tabular}

are given in Table 1 and selected bonds lengths and angles are given in Table 2.

Other linear chain arrangements have been previously described in the literature. For example, Triki and coworkers ${ }^{26}$ 
reported on the $\left[\left\{\mathrm{Cu}(\operatorname{tnH})_{2}\left(\mathrm{H}_{2} \mathrm{O}\right)_{2}\right\}\left\{\mathrm{Fe}(\mathrm{CN})_{6}\right\}\right] \cdot 2 \mathrm{H}_{2} \mathrm{O}$ (tn = 1,2-diaminopropane). Two copper(II)- $\mathrm{N}_{4} \mathrm{O}_{2}$ units are connected via hexacianoferrate(II) bridges, where cyanides are in a trans configuration and the iron ions show an almost perfect octahedral coordination. An interesting case is seen for $\left[\left\{(323)_{2} \mathrm{Cu}_{2}(\mathrm{Cl}) \mathrm{Co}(\mathrm{CN})_{6}\right\}_{n}\right] \cdot 2 \mathrm{nH}_{2} \mathrm{O}$ (323 = N,N'-bis(3-aminopropyl)ethylenediamine), which forms 1-D zigzag chains along the crystallographic axes $a$ and $b$. The propagation is completed by hydrogen bonding interactions between adjacent strings of atoms to form a highly symmetric 3-D network. ${ }^{27}$

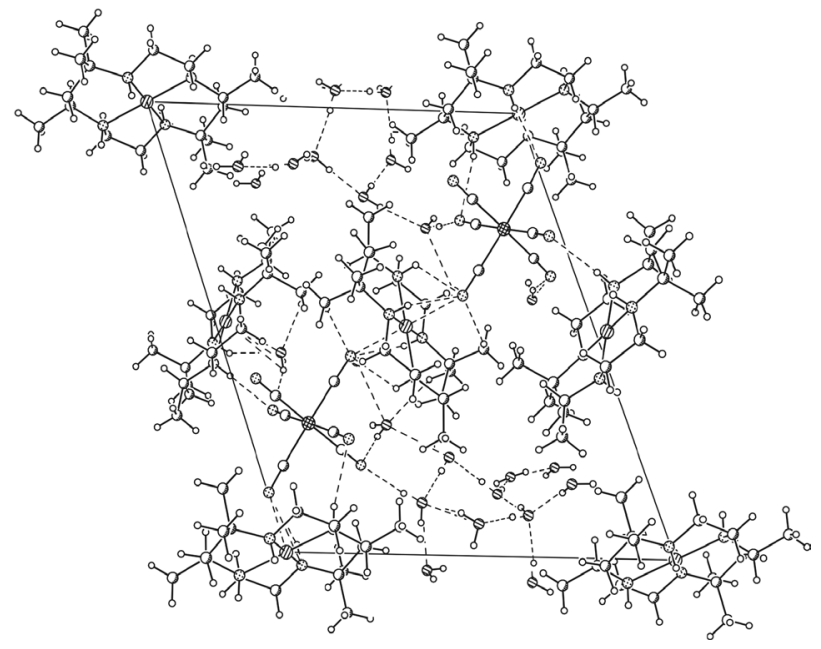

Figure 2. View of the unit cell of $[\mathrm{Cu}(\text { meso })]_{3}\left[\mathrm{Co}(\mathrm{CN})_{6}\right]_{2} \cdot 9.5 \mathrm{H}_{2} \mathrm{O}$ along the $a$ axis, with representation of the H-bonds.

\section{Magnetic properties}

Magnetic measurements were carried out in the temperature range $2-298 \mathrm{~K}$. The plot of $\chi_{\mathrm{M}}$ as a function of temperature is displayed in Figure 3. The effective magnetic moment, $\mu_{\text {efff }}$, at room temperature was determined as being $2.45 \mu_{\mathrm{B}}$, close to the expected spin-only value $\left(2.83 \mu_{\mathrm{B}}\right)$ for two non-interacting copper(II) $(\mathrm{S}=1)$ ions and the diamagnetism of $\left[\mathrm{Co}(\mathrm{CN})_{6}\right]^{3-}$ (low spin cobalt(III) ion, $\mathrm{S}=0)$. The trinuclear $\left[\mathrm{Cu}(\mathrm{dmpn})_{2}\right]_{2}\left[\mathrm{Co}(\mathrm{CN})_{6}\right] \mathrm{ClO}_{4} \cdot 3 \mathrm{H}_{2} \mathrm{O}$ complex reported by Mondal and co-workers exhibited a $\mu_{\text {eff }}$ of $2.50 \mu_{\mathrm{B}}{ }^{14}$ From room temperature down to $3.0 \mathrm{~K}$, $\mu_{\text {eff }}$ remains practically constant, corresponding to two non-interacting $\mathrm{Cu}^{\mathrm{II}}$ ions. Below this point, $\mu_{\text {eff }}$ drops abruptly and reaches $2.20 \mu_{\mathrm{B}}$ at $1.5 \mathrm{~K}$ and under an applied field of 1000 Oe. Analysis of the molar susceptibility was done using the isotropic Heisenberg-Dirac-van Vleck model with the Hamiltonian $H=-2 J \mathrm{~S}_{1} \cdot \mathrm{S}_{2}$ and the theoretical expression for $\chi$ is given elsewhere. ${ }^{28}$

$\chi_{\mathrm{M}}=\left[C(1-p)\left(2 \mathrm{e}^{2 \mathrm{x}}\right) / 1+3 \mathrm{e}^{2 \mathrm{x}}\right]+1 / 4 C p+$ T.I.P.

with $x=|J| / k T$.

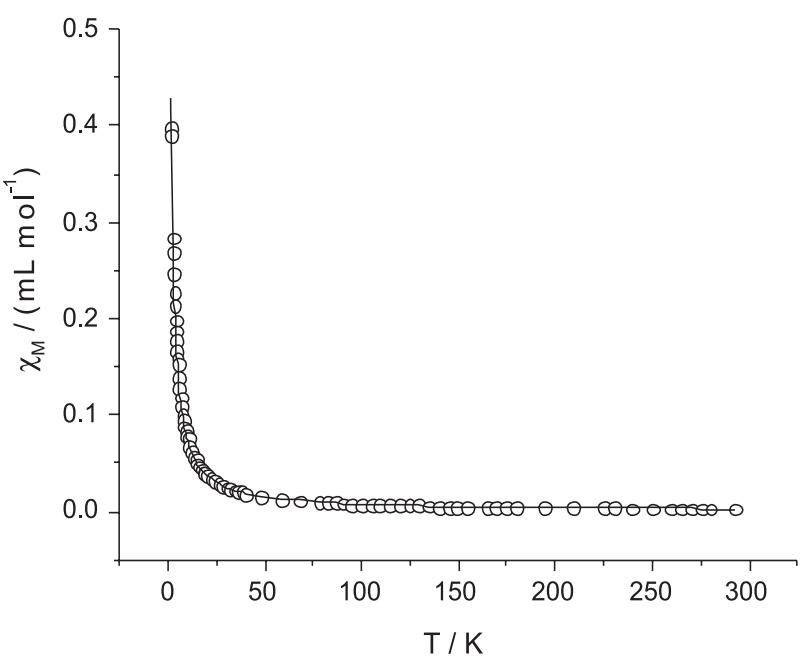

Figure 3. Magnetic susceptibility as a function of temperature for $[\mathrm{Cu}(\mathrm{meso})]_{3}\left[\mathrm{Co}(\mathrm{CN})_{6}\right]_{2} \cdot 9.5 \mathrm{H}_{2} \mathrm{O}$. The solid line is the best fit according to the theoretical expression in the text.

Temperature-independent paramagnetism (TIP) was considered to be $1.00 \times 10^{-6} \mathrm{~mL} \mathrm{~mol}^{-1}$. The expression of $\chi_{\mathrm{M}}$ was corrected to include the fraction $p$ of any paramagnetic impurity present and the Weiss term $\theta$ to account for any intermolecular interactions. Non-linear fittings carried out by varying $J, g, p$ and $\theta$ led to estimated values for parameters of the theoretical expression to the experimental data.

Best fitting lines shown in Figure 3 yielded $J=-0.30 \mathrm{~cm}^{-1}$ and $\mathrm{g}=2.13$ in accordance with a very weak antiferromagnetic interaction between the copper ions. The magnetic interactions are practically insignificant, mainly due to the large value of the $\mathrm{Cu} \cdots \mathrm{Cu}$ separation $(9.609 \AA)$. Also, the magnetic orbital of the copper(II) ion is of the type $\mathrm{d}_{x^{2}-y^{2}}$, with $x$ and $y$ axes defined by the short $\mathrm{Cu}-\mathrm{N}$ bonds, and the axial positions, which are occupied by cyanide ions, have a low-spin density. Although no further experimental support is available, intermolecular interactions between copper(II) in the chain and the isolated $\left[\mathrm{Cu}(\text { meso) }]^{2+}\right.$ can not be ruled out as the $\mathrm{Cu} \cdots \mathrm{Cu}$ separation in this case is slightly lower, $8.467 \AA$.

It is worth note few examples of similar weak magnetic behavior that have been recently published. For example, the one-dimensional copper(II) coordination polymer linked by nitroprusside bridges, $\left[\mathrm{Cu}\left(\mathrm{L}_{2}\right)\right]\left[\mathrm{Fe}(\mathrm{CN})_{5}(\mathrm{NO})\right] \cdot 3 \mathrm{H}_{2} \mathrm{O}$ ( $\mathrm{L}=$ tetraazamacrocycle), with $g=2.12$ and $J=-0.12 \mathrm{~cm}^{-1}$, 29 the heteropolynuclear complex $\left[\left\{(\mathrm{Cu}(\operatorname{dien}))_{2} \mathrm{Co}(\mathrm{CN})_{6}\right\}_{n}\right]$ $\left[\mathrm{Cu}(\right.$ dien $\left.)\left(\mathrm{H}_{2} \mathrm{O}\right) \mathrm{Co}(\mathrm{CN})_{6}\right] \cdot 5 n \mathrm{H}_{2} \mathrm{O}$, where $\mathrm{g}=2.14$ and $J=-1.02 \mathrm{~cm}^{-1} ; ;^{15}\left[\{\mathrm{Cu}(\text { tren }) \mathrm{NC}\}_{2} \mathrm{Co}(\right.$ tren $\left.)\right]$ $\left(\mathrm{ClO}_{4}\right)_{5} \cdot 2 \mathrm{H}_{2} \mathrm{O}$ (tren $=\operatorname{tris}(2$-aminoethyl $)$ amine $)$, with $\mathrm{g}=2.06$ and $J=-0.094 \mathrm{~cm}^{-1} ; 30$ and $\left[\left\{\mathrm{Cu}(\operatorname{tnH})_{2}\left(\mathrm{H}_{2} \mathrm{O}\right)_{2}\right\}\right.$ $\left.\left\{\mathrm{Fe}(\mathrm{CN})_{6}\right\}\right] \cdot 2 \mathrm{H}_{2} \mathrm{O}$, which exhibits a Curie-Weiss constant of $-0.98 \mathrm{~K} .{ }^{26}$ 


\section{Infrared, electronic and EPR spectra}

The infrared spectrum in $\mathrm{KBr}$ is consistent with the structural data presented and has molecular features of the macrocyclic ligand and the cyanometalate core. The occurrence of lattice water in the crystal structure is consistent with the band at $3604 \mathrm{~cm}^{-1}$. Frequencies of the $\mathrm{CN}$ stretching mode provide information about the ligand-bridging mode. The high intensity and lowestfrequency $v(\mathrm{CN})$ band at $2128 \mathrm{~cm}^{-1}$ was assigned to the equatorial terminal cyano ligands and the low intensity high-frequency vibration at $2184 \mathrm{~cm}^{-1}$ to the intermetallic bridging cyanides. For comparison see the polynuclear complex $\left[\mathrm{Cu}(\mathrm{dmpn})_{2}\right]_{3}\left[\mathrm{Co}(\mathrm{CN})_{6}\right]_{2} \cdot 12 \mathrm{H}_{2} \mathrm{O}$, that shows very similar values with bands at 2130 and $2180 \mathrm{~cm}^{-1} .{ }^{14}$ Further, $\left[\mathrm{Fe}(\mathrm{tmphen})_{2}\right]_{3}\left[\mathrm{Co}(\mathrm{CN})_{6}\right]_{2}$ (tmphen $=3,4,7,8$-tetramethyl1,10-phenanthroline) exhibits bands at 2127 and $2167 \mathrm{~cm}^{-1}$, respectively, while the free $\left[\mathrm{Co}(\mathrm{CN})_{6}\right]^{3-} v(\mathrm{CN})$ band appears at $2126 \mathrm{~cm}^{-1}$.

The electronic spectra of $[\mathrm{Cu}(\mathrm{meso})]^{2+}$ in Figure $4 \mathrm{~A}$ shows a low intensity structureless broad band centered at $587 \mathrm{~nm}$, typical of copper(II), and has contributions from three ligand-field transitions: $z^{2} \rightarrow x^{2}-y^{2}, x y \rightarrow x^{2}-y^{2}$ and $(\mathrm{xz}, \mathrm{yz}) \rightarrow \mathrm{x}^{2}-\mathrm{y}^{2} .{ }^{31}$ The $[\mathrm{Cu}(\mathrm{meso})]_{3}\left[\mathrm{Co}(\mathrm{CN})_{6}\right]_{2} \cdot 9.5 \mathrm{H}_{2} \mathrm{O}$ compound exhibited a more symmetric band at $547 \mathrm{~nm}$ with
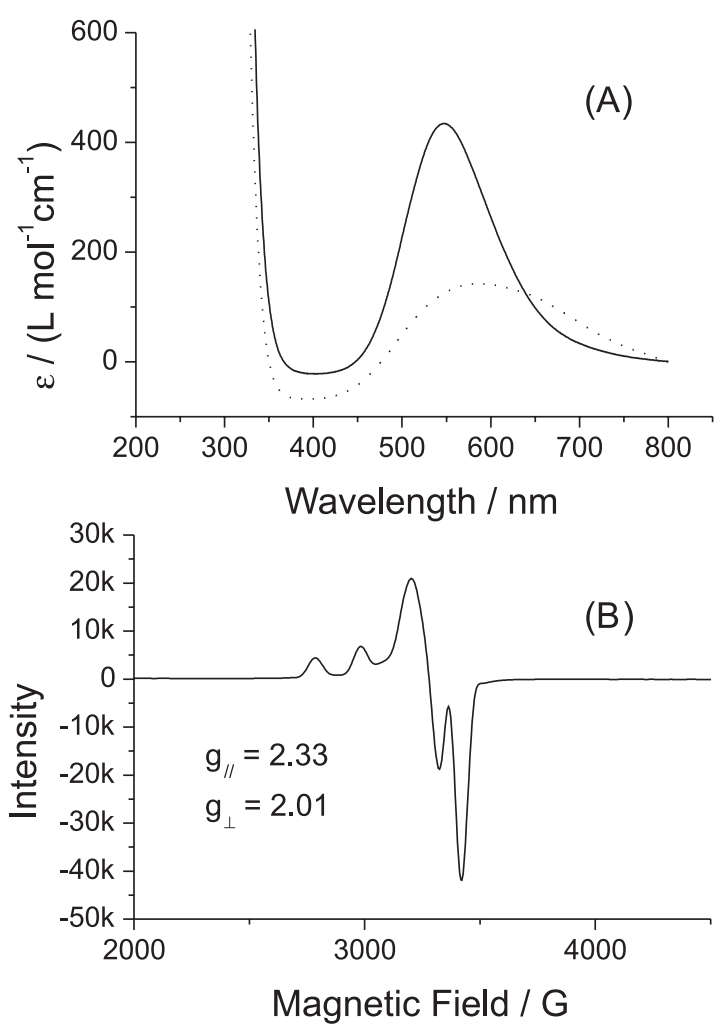

Figure 4. (A) Electronic spectra of $[\mathrm{Cu}(\mathrm{meso})]_{3}\left[\mathrm{Co}(\mathrm{CN})_{6}\right]_{2} \cdot 9.5 \mathrm{H}_{2} \mathrm{O}$ (solid line) and of $\left[\mathrm{Cu}(\text { meso) }]^{2+}\right.$ (dotted line) in dmf. (B) EPR spectra for $[\mathrm{Cu}(\mathrm{meso})]_{3}\left[\mathrm{Co}(\mathrm{CN})_{6}\right]_{2} \cdot 9 \cdot 5 \mathrm{H}_{2} \mathrm{O}$ compound in $\mathrm{dmf}$ at $77 \mathrm{~K}$. a higher intensity, consistent with a significant change in the environment around the copper(II) ion after reacting with $\left[\mathrm{Co}(\mathrm{CN})_{6}\right]^{3-}$. Complex $\left[\mathrm{Cu}(\mathrm{dmpn})_{2}\right]_{3}\left[\mathrm{Co}(\mathrm{CN})_{6}\right]_{2} \cdot 12 \mathrm{H}_{2} \mathrm{O}$ shows a band with a maximum at $590 \mathrm{~nm}$ with the same assignment. ${ }^{14}$

EPR spectrum in dmf at $77 \mathrm{~K}$ (Figure 4B) exhibits a four line EPR spectrum for $\mathrm{Cu}^{2+}, \mathrm{I}=3 / 2$, with parameters $\mathrm{g}_{/ /}=2.33$ and $\mathrm{g}_{\perp}=2.01$. Since $\mathrm{g}_{/ /}>\mathrm{g}_{\perp}$, the unpaired electron resides in the $x^{2}-y^{2}$ orbital. These results are consistently interpreted as being due to a tetragonal distortion around the copper(II) ion, which was also evidenced in the crystal structure by the longer $\mathrm{Cu}-\mathrm{N}_{\text {axial }}$ bond lengths, as discussed above. The hexacyanocobaltate ion is diamagnetic and EPR silent.

\section{Conclusions}

In conclusion, hexacyanocobaltate(III) reacts with $\left[\mathrm{Cu}^{\mathrm{II}}(\mathrm{meso})\right]\left(\mathrm{ClO}_{4}\right)_{2}$ in water producing a $1 \mathrm{D}$-polymeric aggregate formed by two units of $\left[\mathrm{Cu}^{\mathrm{II}}(\mathrm{meso})\right]^{2+}$ bridged by one $(\mu-\mathrm{CN}) \mathrm{Co}^{\mathrm{III}}(\mathrm{CN})_{5}{ }^{3-}$ anion. Single crystal X-ray diffraction analysis revealed a zigzag arrangement of $\mathrm{Co}-\mathrm{CN}-\mathrm{Cu}$ atoms and a packing space in the crystallographic framework filled with water molecules. The copper(II) centers $(S=1 / 2)$ are too far apart and the solid features a small antiferromagnetism. EPR, UV-vis data and bond distances are well in accordance with a significant tetragonal distortion at the copper center.

\section{Supplementary Information}

CCDC-706872 contains the supplementary crystallographic data for this paper. These data can be obtained free of charge at www.ccdc.cam.ac.uk/conts/retrieving.html (or from the Cambridge Crystallographic Data Centre (CCDC), 12 Union Road, Cambridge CB2 1EZ, UK; fax: +44(0)1223-336033; email: deposit@ccdc.cam.ac.uk).

\section{Acknowledgments}

Brazilian Research Councils CNPq, FAPEMIG, FINEP and FAPERJ (Brazil) supported this work. F. H. O. I., F. S. N., M. G. F. V. and N. S. thank CNPq for research fellowships. We also thank LDRX-UFF and Dr. Miguel A. Novak (UFRJ) for magnetic measurements.

\section{References}

1. Cavichiolo, L. J.; Hörner, M.; Crespan, E. R.; Vaz, M. G. F.; Evans, D. J.; Nunes, F. S.; Z. Anorg. Allg. Chem. 2008, 634, 1613. 
2. Ishiruji, F. H. O.; Evans, D. J.; Benedito, F. L.; Nunes, F. S.; Spectrochim. Acta A 2008, 70, 1029.

3. Samanta, B.; Chakraborty, J.; Singh, R. K. B; Saha, M. K.; Batten, S. R.; Jensen, P.; Fallah, M. S. E.; Mitra, S.; Polyhedron 2007, 26, 4354.

4. Chen, W.-T.; Guo, G.-C. ; Wang, M.-S.; Xu, G.; Cai, L.-Z. ; Akitsu, T.; Akita-Tanaka, M.; Matsuhita, A.; Huang, J.-S.; Inorg. Chem. 2007, 46, 2105.

5. Shatruk, M.; Dragulescu-Andrasi, A.; Chambers, K. E.; Stoian, S. A.; Bominaar, E. L.; Achim, C.; Dunbar, K. R.; J. Am. Chem. Soc. 2007, 129, 6104.

6. Rodríguez-Diéguez, A.; Kivekäs, R.; Sakiyama, H.; Debdoubi, A.; Colacio, E.; Dalton Trans. 2007, 2145.

7. Bernhardt, P. V.; Bozoglian, F.; Gonzalez, G.; Martizez, M.; Macpherson, B. P.; Sienra, B.; Inorg. Chem. 2006, 45, 74.

8. Atanasov, M.; Comba, P.; Förster, S.; Linti, G.; Malcherek, T.; Miletich, R.; Prikhod'ko, A. I.; Wadepohl, H.; Inorg. Chem. 2006, 45, 7722.

9. Paraschiv, C.; Andruh, M.; Journaux, Y.; Zak, Z.; Kyritsakas, N.; Ricard, L.; J. Mater. Chem. 2006, 16, 2660.

10. Figuerola, A.; Ribas, J.; Llunell, M.; Casanova, D.; Maestro, M.; Alvarez, S.; Diaz, C.; Inorg. Chem. 2005, 44, 6939.

11. Figuerola, A.; Ribas, J.; Casanova, D.; Maestro, M.; Alvarez, S.; Diaz, C.; Inorg. Chem. 2005, 44, 6949.

12. Chen, X.-Y.; Shi, W.; Xia, J.; Cheng, P.; Zhao, B.; Song, H.-B; Wang, H.-G.; Yan, S.-P.; Liao, D.-Z.; Jiang, Z.-H.; Inorg. Chem. 2005, 44, 4263.

13. Rodriguez, A.; Sakiyama, H.; Masciocchi, N.; Galli, S.; Gálvez, N.; Lloret, F.; Colacio, E.; Inorg. Chem. 2005, 44, 8399.

14. Mondal, N.; Dey, D. K.; Mitra, S.; Gramlich, V.; Polyhedron 2001, 20, 607.
15. Ferbinteanu, M.; Tanase, S.; Andruh, M.; Journaux, Y.; Cimpoesu, F.; Strenger, I.; Rivière, E.; Polyhedron 1999, 18, 3019.

16. Steel, P. J.; Acc. Chem. Res. 2005, 38, 243.

17. Beltran, L. M.; Long, J. R.; Acc. Chem. Res. 2005, 38, 325.

18. Ishiruji, F. H. O.; Nunes, F. S.; Spectrochim. Acta A 2007, 68, 94.

19. Ishiruji, F. H. O.; Evans, D. J.; Hasegawa, T.; Nunes, F. S.; J. Chem. Cryst. 2006, 36, 365.

20. CrysAlis RED, Oxford Diffraction Ltd., Version 1.171.32.38.

21. SCALE3 ABSPACK scaling algorithm. CrysAlis RED, Oxford Diffraction Ltd., Version 1.171.32.38.

22. Sheldrick, G. M.; Schneider, T. R.; Methods Enzymol. 1997, 277, 319 .

23. Sheldrick, G. M.; SHELXL-97; Program for Crystal Structure Refinement; University of Göttingen, Germany, 1997.

24. Johnson, C. K. In Crystallographic Computing; Ahmed, F. R., ed., Munsksgaard: Copenhagen, 1970, pp. 207-220.

25. Curtis, N. F.; J. Chem. Soc. 1964, 2644.

26. Triki, S.; Sala-Pala, J.; Thétiot, F.; Garcia-Gómez, C.; Daran, J-C.; Eur. J. Inorg. Chem. 2006, 185.

27. Saha, M.; Lloret, F.; Bernal, I.; Inorg. Chem. 2004, 43, 1969.

28. Dutta, S. K.; Nanda, K. K.; Flörke, U.; Bhadbhade, N.; Nag. K.; Dalton Trans. 1996, 2371.

29. You, Y. S.; Yoon, J. H.; Lim, J. H.; Kim, H. C.; Hong, C. S.; Inorg. Chim. Acta 2007, 360, 2523.

30. Gu, J-Z.; Kou, H-Z.; Jiang, L.; Lu, T-B.; Tan, M-Y.; Inorg. Chim. Acta 2006, 359, 2015.

31. Protasiewyck, G.; Nunes, F. S. ; Spectrochim. Acta 2006, 65, 549. 